\title{
Resistance of cruciferous crops to turnip root fly
}

\author{
PER RUUTH
}

Svalöf AB, Box 5097, S-900 05 Umeå, Sweden

\begin{abstract}
Cruciferous crops have been investigated for resistance to turnip root fly (Delia floralis Fallén) in northern Sweden. Resistance variation has been demonstrated in field trials by observations of wilting symptoms, differences in green mass yield, root damages, surviving plants and number of eggs. Laboratory methods for resistance studies and plant selections in controlled environment are presented, and a method for rearing of flies is described. The definitions of antixenosis, antibiosis and tolerance are discussed, and suggestions for resistance breeding presented.
\end{abstract}

Index words: turnip root fly, antixenosis, antibiosis, tolerance, resistance breeding

\section{Introduction}

The turnip root fly (Delia floralis Fallén) is the most severe pest of Cruciferous crops in the northern parts of Fennoscandia, while the closely related cabbage root fly (D.brassicae Hoffm.) is of minor importance. The distribution areas of the two species are overlapping, but the turnip root fly is mainly northerly oriented. The local distribution is partly determined by the preference of the turnip root fly for light soils and the preference of the cabbage root fly for heavy soils. The turnip root fly occurs in almost the whole of North Europe with a main distribution area in Fennoscandia, Scotland and North Germany. The species is also found in parts of the Soviet
Union, Manchuria, Korea, North Japan, and North America.

In the northern parts of Norway, Sweden and Finland the turnip root fly has one generation a year. Females hatch at about midsummer, males about one week earlier. The female mates once and deposits the eggs in the soil close to the stem of the host plant where the larvae feed on the roots. In northern Sweden the period of egglaying starts at the end of June and continues until the middle af August. One female can produce 10 to 50 eggs a day and totally up to 250 eggs during their lifetime (VARIS 1967). Egg hatching and larval development is dependent on temperature. Overwintering takes place in the soil in the pupae stage. 
It is of general interest to minimize the use of insecticides in vegetable cultivation. Partial resistance may play an important role for integrated control of insect pests. To study host-plant resistance to insects it is essential that reliable techniques are developed. Different methods for demonstration and measurement of resistance are presented.

\section{The nature of resistance}

Resistance of plants to insects may be due to several factors which can be classified into three main categories:

a) Antixenosis or non-preference. A plant may avoid insect attacks by being unattractive (non-preferred) for shelter, for food or for egglaying.

b) Antibiosis. The plant adversely affects the growth and multiplication of the insect.

c) Tolerance. The plant is able to withstand an infestation of a pest that would severely damage a susceptible plant.

Either separately or in combination these factors impart resistance in a plant to insect attack (Ellis and KemPTON 1981).

Only few papers have been published about resistance to the turnip root fly. Søмme and RYGG (1972) and RygG and Sømme (1972) investigated different factors affecting the oviposition and demonstrated a varying degree of resistance in some varieties of swedes and turnips. Observations of resistance of swedes to turnip root fly have been made also by BIRCH (1985). Alborn et al. (1985) investigated the degree of resistance in different crops and the influence of chemical compounds from the host plant on oviposition behaviour.

Valuable information can also be obtained from studies on the cabbage root fly which has been investigated much more widely. The dispersal in the field and the upwind flight has been studied by FINCH and SKINNER (1975), Hawkes and CoAKer $(1976,1979)$ and HavukKala (1987). The importance of the glucosinolates and their volatile hydrolysis products for the host finding by the cabbage root fly have been investigated by TRAYNIER (1967), Schnitzler and Múller (1969), Ellis et al. (1976), NAIR and McEwen (1976), Finch (1978) and Wallbank and Wheatley (1979). Proкорy et al. (1983), investigated the leaf colour as a factor to distinguish among host plants.

Most interest has been focused to resistance factors affecting oviposition (antixenosis). However, Swailes (1960) showed that antibiosis is an important mechanism in the swede. Matthewman and Lyall (1966) found that resistance of cabbage was due to antixenosis, and Freuler (1978) described a method to select for antibiosis and tolerance in cauliflower.

\section{Demonstration and measurement of resistance in field trials}

The trials presented are performed at Umeå and Haparanda in northern Sweden. The prevalence of root flies is high in the experimental fields, and testing for resistance can be done effectively outdoors each season.

Investigations of root fly populations show that the turnip root fly is the most prevalent species at these localities. From pupae collected in field plots one year the ratio of turnip to cabbage root fly was $7: 1$ at Haparanda and $9: 1$ at Umeå (Alborn et al. 1985).

Other investigations at these two locations show that more than $90 \%$ of the root fly populations consists of the turnip root fly (RuUth, unpubl.).

In field trials the behaviour of the insect has to be considered. Preference for parts of the field can be overcome by using small plots and many randomly distributed replicates.

\section{A general observation trial}

Eighty-six cultivars from 15 cruciferous crops were planted in the field in eight replicates. Each cultivar was represented by eight plants, one plant in each replicate. The plants were about five weeks old when transplanted 
into the field in the middle of June. The distance between plants and between rows was $0.60 \mathrm{~m}$.

Turnip root fly attacks were observed during the summer. Based upon wilting symptoms at the end of August, the plants were classified into four classes: 1 = healthy, 2 = slightly attacked, 3 = heavily attacked and 4 $=$ dead. A mean value for each cultivar was calculated.

The results are shown in Table 1 . The wilting symptoms indicate considerable differences between crops in the resistance to turnip root fly. The variation within crop species is much more expressed compared to the variation between crop species.

\section{Green mass yield of pesticide-treated and untreated plants}

Six cultivars, representing the species B.oleracea, B.campestris and B.napus, were tested at Haparanda and Umeå. Each trial consisted of eight replicates; four were pesticide-treated and four were untreated. Every replicate included thirty plants of each cultivar randomly planted. Observations of turnip root fly attacks were made during the vegetation period. No other pests of importance were observed. In the middle of Septem- ber the green mass was harvested. The relative yield of untreated plants in comparison with pesticide-treated plants within a cultivar is under these conditions used as a measure of resistance to turnip root fly.

As demonstrated in Figure 1, kale (cv Fribor) and turnip rape (cv Torkel) showed no significant differences between treated and untreated plants, indicating a high level of resistance. Chinese cabbage (cv China King), on the other hand, was the most susceptible cultivar tested.

\section{Root damage trials}

Two different crops were investigated. Twenty-two cauliflower cultivars and breeding lines were tested in four replicates with seven plants. Fifteen swede cultivars were represented in 20 replicates with five plants. The distance between rows was $0.50 \mathrm{~m}$ in both trials. Plant distance was $0.50 \mathrm{~m}$ for cauliflower and $0.30 \mathrm{~m}$ for swede.

The plants were about six weeks old when transplanted into the field in the middle of June.

At the end of the vegetation period the roots were investigated and the turnip root fly attacks estimated. The roots were classified into four classes: 1 = roots completely unaffect-

Table 1. Wilting symptoms ( $0-4)$ caused by turnip root fly maggots. $0=$ no visible attack, $4=$ dead plants.

\begin{tabular}{|c|c|c|c|c|}
\hline \multirow[t]{2}{*}{ Crops and species } & & \multirow{2}{*}{$\begin{array}{l}\text { Number of } \\
\text { cvs. tested }\end{array}$} & \multicolumn{2}{|c|}{ Wilting symptoms } \\
\hline & & & Variation & Mean \\
\hline Turnip & Brassica campestris & 7 & $1,0-1,5$ & 1,2 \\
\hline Kale & Brassica oleracea & 3 & $1,1-1,3$ & 1,2 \\
\hline Swede & Brassica napus & 3 & $1,1-1,9$ & 1,5 \\
\hline Winter Rape & Brassica napus & 9 & $1,3-2,1$ & 1,5 \\
\hline Raphanobrassica & R.sativus $x$ B.oleracea & 3 & $1,0-2,0$ & 1,5 \\
\hline Spring rape & Brassica napus & 1 & - & 1,6 \\
\hline Brussels sprouts & Brassica oleracea & 5 & $1,4-1,9$ & 1,6 \\
\hline Cabbage & Brassica oleracea & 14 & $1,1-2,5$ & 1,7 \\
\hline Black radish & Raphanus sativus & 3 & $1,5-2,0$ & 1,8 \\
\hline Spring turnip rape & Brassica campestris & 1 & - & 1,8 \\
\hline Marrow-stem kale & Brassica oleracea & 9 & $1,3-2,1$ & 1,8 \\
\hline Broccoli & Brassica oleracea & 3 & $1,3-2,3$ & 1,9 \\
\hline Chinese cabbage & Brassica campestris & 7 & $1,6-3,4$ & 2,5 \\
\hline Cauliflower & Brassica oleracea & 17 & $1,6-3,8$ & 2,7 \\
\hline White mustard & Sinapis alba & 1 & - & 2,8 \\
\hline
\end{tabular}




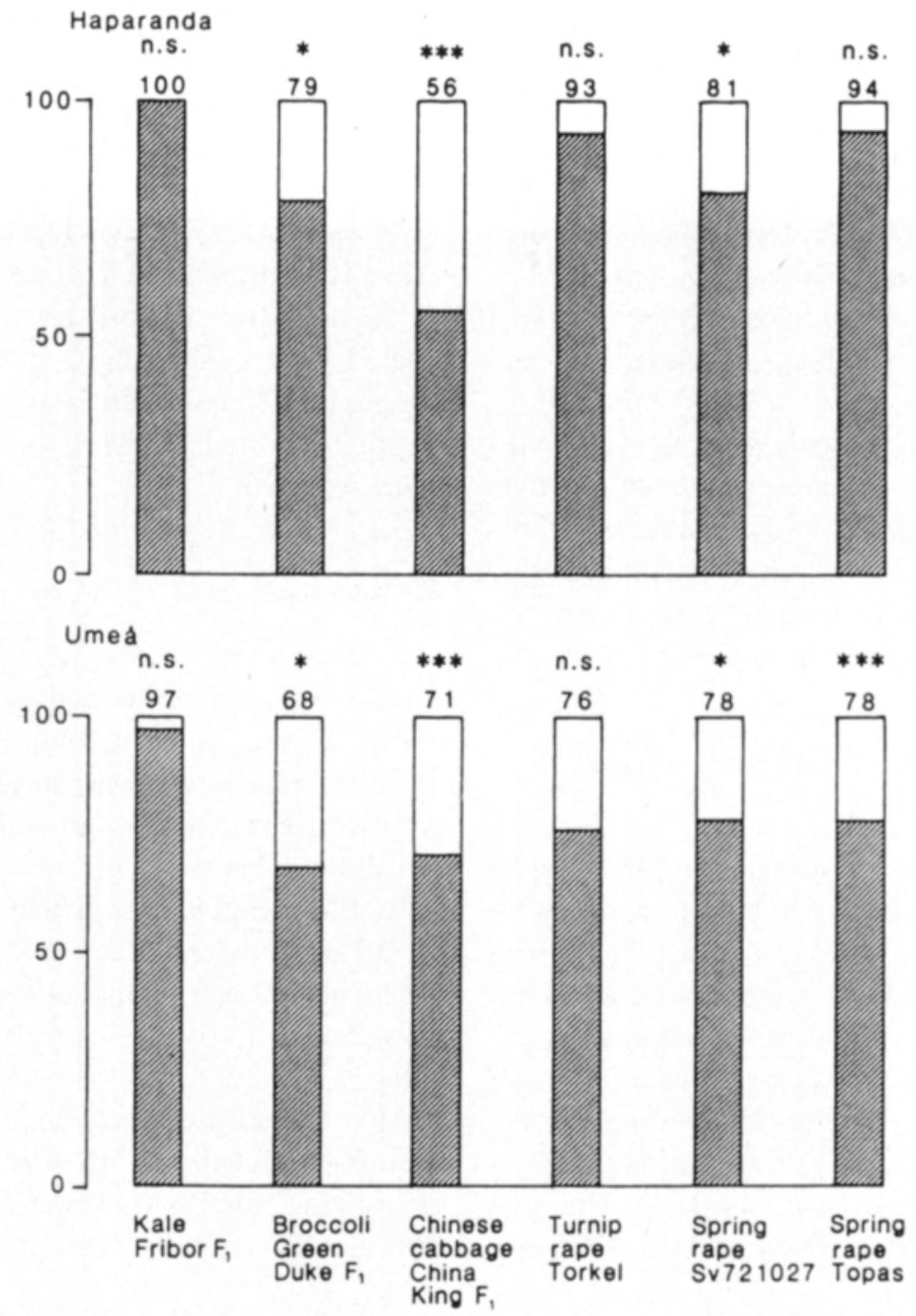

Fig. 1. Comparison of resistance in six cultivars. Green mass yield of untreated plants in relation to pesticidetreated plants at Haparanda and Umeả. Yield of pesticide-treated plants $=100$. Differences tested by Student's t-test $\left(^{*}=\right.$ p $0.05,{ }^{* *}=$ p $0.01,{ }^{* * *}=$ p 0.001$)$.

ed, 2 = slightly affected, $3=$ highly affected and $4=$ completely destroyed. A root damage index (A) was calculated according to Jørgen$\operatorname{sen}(1957): A=100-\frac{3 a+2 b+1 c+0 d}{3}$ where a, b, c and d are the percentages of roots in class 1, 2, 3 and 4, respectively.

An analysis of variance showed that there were significant differences in the root damage index between the cauliflower cultivars. The variety Diana has shown a relatively high level of resistance in comparative trials and the plants have been selected for resistance to turnip root fly. Those lines exhibited less root damage than the common breeding lines of the cultivar Igloo, but the differences were not significant. The results are shown in Figure 2. The root damage index for swede cultivars is presented in Table 2.

\section{Surviving plants and numbers of pupae}

Ten cultivars representing Brassica oleracea, B.campestris, B.napus, Sinapis alba and 
Raphanus sativus were tested at Haparanda and Umeå. Potted plants were placed in the field from the middle of June to the beginning of September. Each cultivar consisted of 30 plants distributed in three replicates. After the vegetation period the number of surviving plants was recorded, and the pupae in each pot determined to species and counted.

Plant survival and numbers of pupae collected are presented in Table 3. The numbers of pupae differed significantly between cultivars.

Using the percentage of surviving plants as a measure, the kale Fribor and the spring rape line Sv 721027 show the highest level of resistance. The cauliflower lines and the Chinese cabbage line were the most susceptible cultivars tested.

The value of the correlation coefficient (r) for percentage of surviving plants related to the number of pupae per plant shows no considerable correlation, indicating differences in tolerance among cultivars tested. The spring rape line Sv 721027 and the turnip rape Torkel show a high level of tolerance in contrast to the cauliflower lines.

\section{Number of eggs}

The same cultivars as in the above trial were tested for antixenosis. The number of eggs deposited around each plant was counted.

Plants were grown in plastic pots in the greenhouse and the soil surface was covered with sand (grain size $1-2 \mathrm{~mm}$ ). The eggs were separated from the sand by flotation and counted on a black mesh. At four different times in July, 20 pots of each cultivar were placed in the field. When exposed for oviposition, the plants were $7,8,11$ and 12 weeks old. To detect the influence of plant age, two different ages were represented at the same time in the field.

The mean egg numbers calculated over the four turns are presented in Figure 3. In spite of a considerable variation of egg numbers within cultivars, the differences were significant in all four turns (Fig. 3). Kale (cv Fribor)

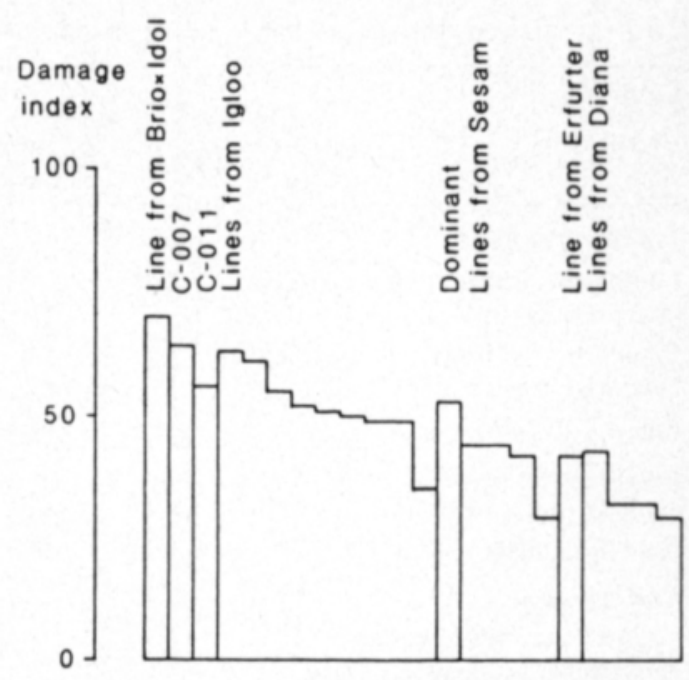

Fig. 2. Root damages by the turnip root fly in cauliflower. Index according to Jørgensen: 0 = root completely unaffected, 25 = slightly affected, 50 = heavily affected, $100=$ completely destroyed.

and Chinese cabbage (cv C-902) were the extremes. The differences among the cauliflower lines as well as among the cultivars of rape were not significant, but correlated with the differences in survival shown in Table 3 .

The mean egg number differs significantly with plant age in the investigated cultivars in two of the replicates and the "critical age" seems to differ among the cultivars tested.

Table 2. Root damage by the turnip root fly in swede. Index according to Jørgensen: 0 = roots completely unaffected, $25=$ slightly affected, 50 $=$ highly affected, $100=$ completely destroyed.

Cultivar Index

Mustiala 35

Angus 35

Vige 37

Măăttă 43

Wilhelmsburger $\quad 43$

Östgöta II 44

Gry $\quad 46$

Bangholm Ruta $\quad 46$

Gullåker III $\quad 46$

Svensk Gul $\quad 48$

Melfort $\quad 54$

Western Perfection $\quad 58$

Globus $\quad 59$

Alta Sweet $\quad 63$ 
Table 3. Potted plants exposed to local populations of the turnip root fly.

\begin{tabular}{|c|c|c|c|c|}
\hline \multirow[t]{2}{*}{ Cultivar } & \multicolumn{2}{|c|}{ Haparanda } & \multicolumn{2}{|c|}{ Umeá } \\
\hline & $\begin{array}{l}\text { Surviving } \\
\text { plants } \%\end{array}$ & $\begin{array}{c}\text { Pupae } \\
\text { per plant }\end{array}$ & $\begin{array}{l}\text { Surviving } \\
\text { plants } \%\end{array}$ & $\begin{array}{c}\text { Pupae } \\
\text { per plant }\end{array}$ \\
\hline \multicolumn{5}{|l|}{ Brassica oleracea } \\
\hline $\begin{array}{l}\text { Cauliflower with low root damage } \\
\text { index (Diana line) }\end{array}$ & 17 & 18 & 60 & 10 \\
\hline $\begin{array}{l}\text { Cauliflower with high root damage } \\
\text { index (Igloo line) }\end{array}$ & 13 & 22 & 50 & 20 \\
\hline Kale cv. Fribor & 97 & 17 & 100 & 14 \\
\hline \multicolumn{5}{|l|}{ Brassica campestris } \\
\hline Turnip rape cv. Torkel & 90 & 41 & 93 & 69 \\
\hline Chinese cabbage C-902 & 23 & 47 & 50 & 43 \\
\hline \multicolumn{5}{|l|}{ Brassica napus } \\
\hline $\begin{array}{l}\text { Fodder rape with low total } \\
\text { glucosinolate content cv. Samo }\end{array}$ & 37 & 64 & 73 & 67 \\
\hline Fodder rape cv. Fora & 63 & 66 & 90 & 59 \\
\hline $\begin{array}{l}\text { Spring rape with high total } \\
\text { glucosinolate content. Sv } 721027\end{array}$ & 97 & 41 & 100 & 58 \\
\hline \multicolumn{5}{|l|}{ Sinapis alba } \\
\hline White mustard cv. Trico & 1) & 16 & 2 & 29 \\
\hline \multicolumn{5}{|l|}{ Raphanus sativus } \\
\hline \multirow{2}{*}{ Black radish cv. Pegletta } & 87 & 81 & 70 & 92 \\
\hline & \multicolumn{2}{|c|}{$r=-0,22$} & \multicolumn{2}{|c|}{$r=-0,30$} \\
\hline
\end{tabular}

1) Plants killed because of mechanical damage.

\section{Studies of resistance in controlled environment}

In order to find a rapid screening technique for selection of resistant plants and for resistance studies throughout the year, laboratory methods have been developed. As both the resistance of test plants and the behaviour of the insects might be influenced by the environment in the laboratory or the greenhouse it is necessary that results obtained from such tests are confirmed in field trials.

The test plants were randomized on a turntable (Ellis and Hardman 1975) inside a cage $(1,50 \times 1,50 \times 0,65 \mathrm{~m})$ placed in the laboratory and containing turnip root flies of different ages. Each batch of 90 plants received three one-day exposures to egglaying. The positions of the plants within the test chamber were changed for each exposure to ensure complete randomization. In the pots the upper soil layer was sand to make egg separation by flotation possible.

A laboratory population of the turnip root fly has been established from pupae collected in different fields in northern Sweden. The flies were reared on swedes put halfway down into sand in clay pots. The eggs were collected around slices of swedes exposed to egglaying females.

The distribution of eggs around the swedes in the pots was approximately one egg per gram of swede. The pots were covered with plastic during the egg hatching period to ensure high humidity. About 10 days later, when the larvae started to feed, the plastic covers were exchanged to pots of the same type as the ones containing sand but placed upside down. Adults hatched about eight weeks after egglaying at $+20^{\circ} \mathrm{C}$, during a period from April to October. However, during the winter period, most pupae went into diapause. No 


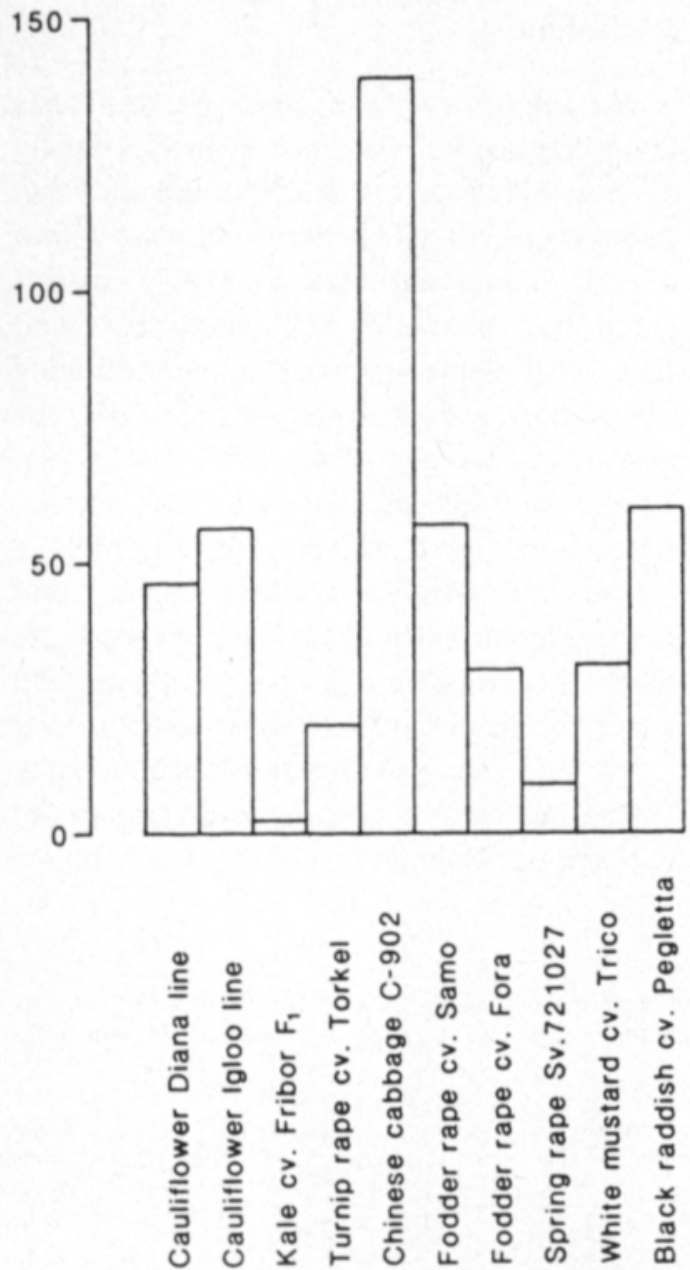

Fig. 3. Comparison of resistance to oviposition by the turnip root fly in 10 cruciferous crops. Mean egg number after field exposure of 7-, 8-, 11-, and 12-week-old potted plants.

selection among flies for non-diapausing occurred but the pupae could be stored in diapause at low temperatures for up to one year. After three months at $+5^{\circ} \mathrm{C}$, about 70 percent of the pupae began to hatch after 6 weeks at $+20^{\circ} \mathrm{C}$.

\section{Oviposition on different crops}

The same cultivars tested for resistance in the field were tested for oviposition in the turntable cage. There were 12 plants, 6 weeks old, of each cultivar. The mean numbers of eggs are presented in Table 4.
Table 4. Egglaying around 6-week-old potted plants randomized on a turntable in a laboratory cage.

\begin{tabular}{lr}
\hline Cultivar & Eggs per plant \\
\hline Kale cv. Fribor & 1,3 \\
Broccoli cv. Green Duke & 1,3 \\
Chinese cabbage cv. China King & 49,3 \\
Turnip rape cv. Torkel & 46,7 \\
Spring rape Sv 721027 & 7,0 \\
Spring rape cv. Topas & 14,6 \\
Control, lettuce & 2,8 \\
\hline
\end{tabular}

\section{Kale, Chinese cabbage and rape}

Six cultivars of kale, two cultivars of Chinese cabbage and three cultivars of rape were tested separately in the turntable cage. Each cultivar was tested with 4-, 6- and 8 -week old plants. The number af plants per cultivar in each batch was 15 for kale, 45 for Chinese cabbage and 30 for rape. The number of eggs per plant was calculated as a measure of antixenosis.

The degree of antixenosis varied considerably between cultivars as shown in Table 5 . The two Chinese cabbage cultivars differed significantly at all three plant ages in agreement with field observations for total resistance. The differences in kale were not expressed at four weeks which may be due mainly to a small fly population. Differences in antixenosis between the rape cultivars were not expressed at four and six weeks age but a eight weeks. The spring rape line Sv 721027 , high in total glucosinolate content, was less preferred than Fora and Samo, two fodder rape cultivars (winter rape types).

Comparison of oviposition between different plant ages is not adequate here because of the differences in number of eggs totally deposited at each turn.

\section{Cauliflower}

Four cauliflower cultivars chosen on observations of resistance in field trials, were tested for resistance. Each cultivar was represented by 80 plants, six weeks old. Forty plants 
of each cultivar distributed in four replicates were exposed to oviposition in the turntable cage and after that transferred to a greenhouse during larval development. A root damage index was calculated as a measure of total resistance. The remaining 40 plants, distributed in the same way, were infested with 10 turnip root fly eggs per plant in the greenhouse. A root damage index was calculated as a measure of tolerance and/or antibiosis.

When plants were exposed to oviposition, the Dianaline $\mathrm{Hg} 54929$ was significantly less damaged, indicating a higher level of resistance in agreement with field trials. When infested by an equal number of eggs, the Dianaline was significantly the most damaged. The observations, presented in Table 6, indicate that antixenosis is of major importance for the total resistance in the Dianaline.

\section{Discussion}

The importance of antixenosis, antibiosis and tolerance for resistance to turnip root fly by host-plants seems to differ not only between crops but also between cultivars within a crop. Finch and ACKLEY (1977) investigated cultivated and wild host-plants and found that plants preferred for oviposition by the cabbage root fly were not necessarily the best for the larvae to feed on and vice versa. These results indicate that antixenosis and antibiosis may have evolved independently.

The preference for Chinese cabbage and non-preference for kale demonstrated in laboratory trials were in agreement with field observations of oviposition. Except for these crops, differences in total resistance shown in field trials do not agree with differences in antixenosis exhibited in the laboratory for six-

Table 5. Egglaying in different crop cultivars. 4-, 6- and 8-week-old potted plants randomized on a turntable in a laboratory cage. Number of eggs per plant. Differences tested by the analysis of variance $\left(^{*}=\mathrm{p} 0,05\right.$, $* *=\mathrm{p} 0,01, * * *=\mathrm{p} 0,001)$.

\begin{tabular}{|c|c|c|c|}
\hline Cultivar & 4-wk & 6-wk & 8 -wk \\
\hline \multicolumn{4}{|l|}{ Chinese cabbage } \\
\hline Early Top (least damaged in field plots) & 1,1 & 2,8 & 2,1 \\
\hline Hongkong (most damaged in field plots) & 8,6 & 12,1 & 7,0 \\
\hline Significance & $* * *$ & $*$ & $* * *$ \\
\hline \multicolumn{4}{|l|}{ Kale } \\
\hline Dakribor & 0 & 1,3 & 6,7 \\
\hline Halvhög & 0 & 3,0 & 11,5 \\
\hline Nedribor & 0 & 5,1 & 14,3 \\
\hline Winterbor & 0,7 & 7,6 & 17,5 \\
\hline Fribor & 0 & 9,7 & 16,4 \\
\hline Smaragd & 0,4 & 17,5 & 19,7 \\
\hline Significance & n.s. & ** & ** \\
\hline \multicolumn{4}{|l|}{ Rape } \\
\hline Sv 721027 (high in total glucosinolates) & 6,0 & 15,1 & 2,9 \\
\hline Fora & 8,1 & 14,2 & 13,3 \\
\hline Samo (low in total glucosinolates) & 9,7 & 13,1 & 16,0 \\
\hline Significance & n.s. & n.s. & $* *$ \\
\hline
\end{tabular}

Table 6. Laboratory observations of resistance to turnip root fly in four cauliflower cultivars. Root damage index (RDI) according to Jørgensen.

\begin{tabular}{lcccr}
\hline & White Top & Igloo II & C-026 & Hg 54929 \\
\hline RDI after oviposition & 54 & 74 & 58 & 36 \\
RDI after inoculation & 40 & 74 & 66 & 85 \\
\hline
\end{tabular}


week-old plants. This fact may be explained by the influence of antibiosis and tolerance on total resistance or by plant age-dependent antixenosis.

Plant age is an important factor influencing the non-preference resistance to turnip root fly. This has earlier been shown for resistance of radish to cabbage root fly (ELLIS et al. 1979).

The biochemical composition of plants often changes with age, and this makes them more resistant at one stage of growth than at another. Obviously, antixenosis is of great importance for the total resistance of a cultivar in choice situations to the pest. However, the value of antixenosis in no-choice situations has to be investigated more extensively. AlBorn et al. (1985) concluded that chemical plant characteristics associated with the leaf surface were of crucial importance for the oviposition behaviour of the turnip root fly and point out that more efforts should be put to screening of non-host Cruciferae for oviposition repressors.

Investigations on antibiosis can be done by observing larval penetration and survival on the roots, weight of pupae or by other bioassay techniques. Antibiosis to cabbage and turnip root fly larvae has previously been demonstrated in swedes (Svalles 1960, Birch, unpubl.). Perhaps higher levels of antibiosis should be looked for in wild plant material. In the future, antibiosis can be assumed to be the most interesting field for genetic engineering to produce cultivars highly resistant to insect pests.

The volume and depth of the root system and the capacity of regenerating new root tissues are of importance for plant characteristics connected with vigour and drought resistance. These qualities are also of crucial importance for tolerance to root larvae attacks. Rape and turnip rape cultivars, for instance, often show high tolerance in contrast to cauliflower and Chinese cabbage cultivars. In combination with antixenosis or antibiosis, tolerance can be of major importance in saving a crop from pest damage. However, in the long run, tolerance alone is of limited value for pest control, because the pest population tends to increase.

Evidently, there are possibilities to increase the level of resistance to insects by several crops by plant breeding. Many of the insect pests in the world are today controlled by resistant cultivars. By the use of pesticides in selection fields many genes for resistance have already been lost from present cultivars. It is therefore often necessary to search among wild relatives of the crop plants to find satisfactory levels of resistance to a particular pest. Unfortunately, this would make the breeding work considerably more complex and timeconsuming. Perhaps in a not too distant future, it will be possible to speed up the breeding work by means of modern biotechnology.

Breeding for resistance to insects deals more with the level of resistance than absolute resistance. Absolute resistance, as in certain lettuces to root aphids, is rarely achieved. However, for an integrated control of a pest, partial resistance may play an important role. This has been shown in carrots for control of the carrot fly (Psila rosae. Fabricius). Significant differences exist between certain cultivars in the incidence of damaged roots (ElLIS et al. 1980). It has been shown that insecticide treatment and host-plant resistance are complementary factors, which means that, for instance, the same degree of carrot fly control was achieved with less insecticide on resistant than on susceptible cultivars (THOMPSON et al. 1980). It is of great importance to investigate the role of partial resistance for integrated control of the turnip root fly as well.

In Scotland, breeding for resistance to turnip root fly of swede is in progress and partially resistant cultivars are used in commercial cultivation.

CRISP et al. (1977) pointed out that selection for resistance to cabbage root fly in cauliflower may increase the level of plant resistance. Eluis et al. (1984) found that progenies from crosses between two promising taxonomic types of cauliflower possessed greater resistance than either parent. How- 
ever, selections within any of the parents did not improve resistance. Resistance of cauliflower was found to be related to the vigour of the root system.

At the plant breeding company Svalöf $\mathrm{AB}$ in Sweden, the possibilities for resistance breeding of different Brassica crops have been investigated. Studies of crosses between cauliflower and kale implies the possibility to transfer the resistance to turnip root fly from kale to cauliflower or to other related crops. Repeated selections for antixenosis in fodder rape affected total resistance. The influence of plant age, however, must be investigated more extensively before it is possible to develop non-preference resistant cultivars.

Search for other gene sources are in progress. Some wild Brassica collections, mainly from the Mediterranean area, have been tested at Svalöf AB. In field trials, resistance correlated highly with root volume but did not exceed the resistance level of kale.

Acknowledgement. This study was supported by the Swedish Plant Breeding Board.

\section{References}

Alborn, H., Karlsson, H., Lundgren, L., Ruuth, P. \& Stenhagen, G. 1985. Resistance in crop species of the genus Brassica to oviposition by the turnip root fly, Hylemya floralis. - Oikos 44: 61-69.

BIRCH, N. Integrated Plant Protection in Field Vegetables. Proc. IOBC/CEC Joint Experts Meeting. 1985.

Crisp, P., Ellis, P.R., Hardman, J.A. \& Gray, A.R. 1977. Susceptibility of Cauliflower Types to Cabbage Root Fly. Eucarpia Cruciferae Newsletter 2: 18-19.

Eluis, P.R. \& HaRdMan, J.A. 1975. Laboratory methods for studying nonpreference resistance to cabbage root fly in cruciferous crops. Ann. Appl. Biol. 79: 253-264.

- \& Kempton, D.P.H. 1981. Progress in the Studies of Resistance of Vegetable Crops to Insect Attack. Sci. Hort. 32: 60-67.

-, Cole, R.A., Crisp, P. \& Hardman, J.A. 1980. The relationship between cabbage root fly egglaying and volatile hydrolysis products of radish. - Ann. Appl. Biol. 95: 283-289.

-, Hardman, J.A., Crisp, P. \& Johnson, A.G. 1979. Influence of plant age on resistance of radish to cabbage root fly egg-laying. - Ann. Appl. Biol. 13: 125-131.

-, Hardman, J.A., Crisp, P., Johnson, A.G. \& Cole, R.A. 1976. Resistance of brassicas and radish to cabbage root fly. - Rep. Natn. Veg. Res. Stn. for 1975: $88-90$.

-, Hardman, J.A., Crisp, P. \& Gray, A.R. Investigations of Resistance in Cauliflowers to Cabbage Root Fly Attack. Proc. Better Brassicas Conference. 1984.

FinCH, S. 1978. Volatile plant chemicals and their effect on host plant finding by the cabbage root fly (Delia brassicae). - Ent. Exp. Appl. 24: 350-359.

— \& ACKıEY, C.M. 1977. Cultivated and wild host plants supporting populations of the cabbage root fly. - Ann. Appl. Biol. 85: 13-22.

- \& Skinner, G. 1975. Dispersal of the cabbage root fly. - Ann. Appl. Biol. 81: 1-19.

Freuler, J. 1978. Glasshouse studies of the effects of cabbage root fly larvae, Delia brassicae (Hoffm.) (Dipt., Anthomyiidae) on cauliflower varieties. Z. ang. Ent 86: 98-105.

Havukkala, I. Odour Source Finding Behavior of Delia brassicae in the field. Proc. 5th Int. Symp. Insect-Plant Relationships. 1987.

Hawkes, C. \& CoAKer, T.H. 1976. Behavioural responses to host-plant odours in adult cabbage root fly (Erioischia brassicae (Bouché)). - Symp. Biol. Hung. 16: 85-89.

- \& Conker, T.H. 1979. Factors affecting the behavioural responses of the adult cabbage root fly, $D e$ lia brassicae, to host plant odour. - Ent. Exp. Appl. 25: $45-58$.

Jørgensen, J. 1957. Den store kâlflue (Cortophila floralis Fall.). Nyere undersøgelser vedrørende dens biologi, parasitering og bakæmpelse. - Tidskr. Planteavl. 60: $657-712$.

Matthewman, W.G. \& Lyall, L.H. 1966. Resistance in Cabbage to the Cabbage Maggot, Hylemya brassicae (Bouché) Can. Ent. 98: 59-69.

NAIR, K.S.S. \& McEwEN, F.L. 1976. Host selection by the adult cabbage maggot, Hylemya brassicae (Diptera: Anthomyiidae): Effect of glucosinolates and common nutrients on oviposition. - Can. Ent. 108: 1021-1030.

-, McEwen, F.L. \& SNieckus, V. 1976. The relationship between gluckosinolate content of cruciferous plants and oviposition preferences of Hylemya brassicae (Diptera: Anthomyiidae). - Can. Ent. 108: 1031-1036.

Prokopy, R.J., Collier, R.H. \& FinCH, S. 1983. Leaf colour used by cabbage root flies to distinguish among host plants. Science 221: 190-192.

RygG, T. \& Søмme, L. 1972. Oviposition and larval development of Hylemya floralis (Fallén) (Dipt., Anthomyiidae) on varieties of swedes and turnips. Norsk Ent. Tidskr. 19: 81-90. 
SChnitzler, W.H. \& Móler, H.P. 1969. Über die Lockwirkung eines Senföls (Allylisothiocyanat) auf die grosse Kohlfliege, Phorbia floralis Fallén. - Z. Angew. Ent 63: 1-8.

Swalles, G.E. 1960. Laboratory Evaluation of Resistance in Rutabaga Varieties to the Cabbage Maggot, Hylemya brassicae (Bouché) (Diptera: Anthomyiidae) Can. Ent. 92: 958-960.

Søмme, L. \& Rygo, T. 1972. The effect of physical and chemical stimuli on oviposition in Hylemya floralis (Fallén) (Dipt., Anthomyiidae). - Norsk Ent. Tidskr. 19: 19-24.

Thompson, A.R., Ellus, P.R., Percivall, A.L. \& HardMAN, J.A. 1980. Carrot fly. Integrated control using insecticides with carrot cultivars of differing suscepti- bilities. Report of the National Vegetable Research Station for 1979: 30.

TrAYNIER, R.M.M. 1967 a. Effect of host plant odour on the behaviour of the adult cabbage root fly, Erioischia brassicae. - Ent. Exp. Appl. 10: 321-328.

-1967 b. Stimulation of oviposition by the cabbage root fly Erioischia brassicae. - Ent. Exp. Appl. 10: $401-412$.

VARIS, A-L. 1967. Studies on the biology of the cabbage root fly (Hylemya brassicae Bouché) and turnip root fly (Hylemya floralis Fallén). Ann. Agr. Fenn. 6: 1-13.

Wallbank, B.E. and Wheatley, G.A. 1979. Some responses of cabbage root fly (Delia brassicae) to allyl isothiocyanate and other volatile constituents of crucifers. - Ann. Appl. Biol. 91: 1-12.

\section{SELOSTUS}

\section{Ristikukkaiskasvien kestävyys isokaalikärpästä vastaan}

\section{Per Ruuth}

\section{Svalof $A b$,}

Box 5097, S-900 05 Umeá, Sweden

Tutkimuksen kohteena on ollut 15 ristikukkaislajin kestăvyys isokaalikärpästä (Delia floralis Fallén) vastaan Pohjois-Ruotsissa. Kestävyyden muuntelu on kenttäkokeissa esiintynyt lakastumissymptomeina, eroina vihreän massan tuotossa, juurivioituksissa, elävănă selviävien kasvien ja munien lukumäărissä. Artikkelissa esitellään kes-

tävyystutkimuksen laboratoriomenetelmiä, valintaa valvotuissa olosuhteissa ja kärpästen kasvatuskeino. Tarkastelussa määritellaaan käsitteet antixenoosi, antibioosi ja toleranssi ja tehdään ehdotuksia kestävyysjalostuksen suorittamiseksi. 